Int. J. Dev. Biol. 57: 715-724 (2013)

doi: $10.1387 / \mathrm{ijdb} .130173$ to

\title{
Long-term serial cultivation of mouse induced pluripotent stem cells in serum-free and feeder-free defined medium
}

\author{
SACHIKO YAMASAKI' ${ }^{1}$ KOU NABESHIMA ${ }^{1}$, YUSUKE SOTOMARU ${ }^{2}$, YUKI TAGUCHI ${ }^{3}$, \\ HANAE MUKASA ${ }^{3}$, MIHO K. FURUE ${ }^{4}$, J. DENRY SATO ${ }^{5}$ and TETSUJI OKAMOTO*,1
}

\begin{abstract}
${ }^{1}$ Department of Molecular Oral Medicine and Maxillofacial Surgery, Applied Life Sciences, Institute of Biomedical \& Health Sciences, Hiroshima University, ${ }^{2}$ Natural Science Center for Basic Research and Development, Hiroshima University ${ }^{3}$ Department of Molecular Oral Medicine and Maxillofacial Surgery, Division of Frontier Medical Sciences, Graduate School of Biomedical \& Health Sciences, Hiroshima University, Hiroshima, Japan ${ }^{4}$ Laboratory of Cell Cultures, Department of Disease Bioresources, National Institute of Biomedical Innovation, Osaka, Japan and ${ }^{5}$ Manzanar Project Foundation, Wenham, MA, USA
\end{abstract}

\begin{abstract}
Mouse embryonic stem (mES) cells and mouse induced pluripotent stem (miPS) cells are commonly maintained on inactivated mouse embryonic fibroblast feeder cells in medium supplemented with fetal bovine serum or proprietary replacements. An undefined medium containing unknown quantities of reagents has limited the development of applications for pluripotent cells because of the relative lack of knowledge regarding cell responses to differentiating growth factors. Therefore we developed a serum-free medium, designated ESF7, in which mES cells can be maintained in an undifferentiated state without feeder cells. The medium was tested for culturing miPS cells. The miPS cells have been maintained in ESF7 medium for more than $\mathbf{3}$ years with an undifferentiated phenotype manifested by the expression of pluripotency marker genes and alkaline phosphatase, and these cells exhibited largely normal karyotypes. Furthermore, we found that fibroblast growth factor-2 (FGF-2) with heparin induced miPS cell differentiation into neuronal cells, both in an adherent monolayer and in embryoid body suspension culture. Moreover, we found that FGF-2 with bone morphogenetic protein 2 induced miPS cell differentiation into cardiomyocytes in embryoid body suspension culture. Furthermore, we transplanted subcutaneously miPS cells maintained in ESF7 into the dorsal flanks of SCID mice; all of the transplants produced tumors with tissues derived from all three embryonic germ layers. As this simple serum-free adherent monoculture system supports the long-term propagation of pluripotent iPS cells in vitro, it will allow us to elucidate cell responses to growth factors under defined conditions, and it should provide useful information for differentiation protocols for human iPS cells.
\end{abstract}

KEY WORDS: iPS cell, serum-free, LIF, neural differentiation, cardiomyocyte

\section{Introduction}

In recent years, extensive investigations into improving culture systems for embryonic stem (ES) cells (Chung et al., 2005) and pluripotent stem (iPS) cells (Takahashi et al., 2006) have been carried out. These stem cells had the potential to differentiate into tissues from all three embryonic germ layers (Takahashi et al., 2007; Okita et al., 2007; Kaufman et al., 1983; Martin 1981). Mouse ES cells and iPS cells represent models of mammalian development that enable biochemical and molecular analyses. Recently, ES cell biology has become a focus for biotechnology and regenerative medicine. Major limitations of the use of stem cells in a variety of biotechnological applications are the current requirement for feeder cells and the relative lack of knowledge regarding the long-term maintenance of pluripotency. A simple experimental system in which rules governing pluripotency and differentiation could be deciphered would encourage the development of new

Abbreviations used in this paper: BMP-2, bone morphogenetic protein-2; FGF-2, fibroblast growth factor-2; LIF, leukemia inhibitory factor; MEF, mouse embryonic fibroblast; mES cells, mouse embryonic stem cells; miPS cells, mouse induced pluripotent stem cells.

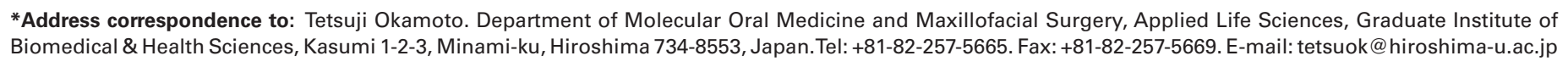

Supplementary Material (movie, figure and table) for this paper is available at: http://dx.doi.org/10.1387ijdb.130173to 
stem cell applications.

Mouse ES cells and iPS cells are commonly maintained on inactivated primary mouse embryonic fibroblast (MEF) feeder cells in culture medium supplemented with serum and leukemia inhibitory factor (LIF). Previous studies demonstrated that selfrenewal and pluripotency could be maintained under these culture conditions (Smith et al., 1988). In the absence of LIF, iPS cells differentiate spontaneously in serum-containing culture medium (Takahashi et al., 2007). Culture protocols have been developed recently that permit the derivation of some types of cells from undifferentiated ES and iPS cells (Chung et al., 2005; Takahashi et al., 2006; Takahashi et al., 2007; Okita et al., 2007). However, because these procedures require the cultivation of ES and iPS cell aggregates and conditioned medium containing undefined components or feeder cells, they produce variable and heterogeneous results (Furue et al., 2005; Sato et al., 2010; Hayashi et al., 2007). Differentiation protocols based on knowledge of ES/ iPS cell responses to specific growth factors are not currently available for most types of mouse cells. However the clinical translation of iPS cell-based therapeutic strategies will require clear knowledge of the potential responses of these cells in vitro and in vivo.

In this study, we describe a serum-free culture medium ESF7, in which a novel mitogenic activity of LIF was uncovered and iPS cell self-renewal and pluripotency were maintained during longterm serial cultivation in the absence of feeder cells. Using this culture system, it will be possible to elucidate the developmental responses of ES and iPS cells to specific environmental stimulation.
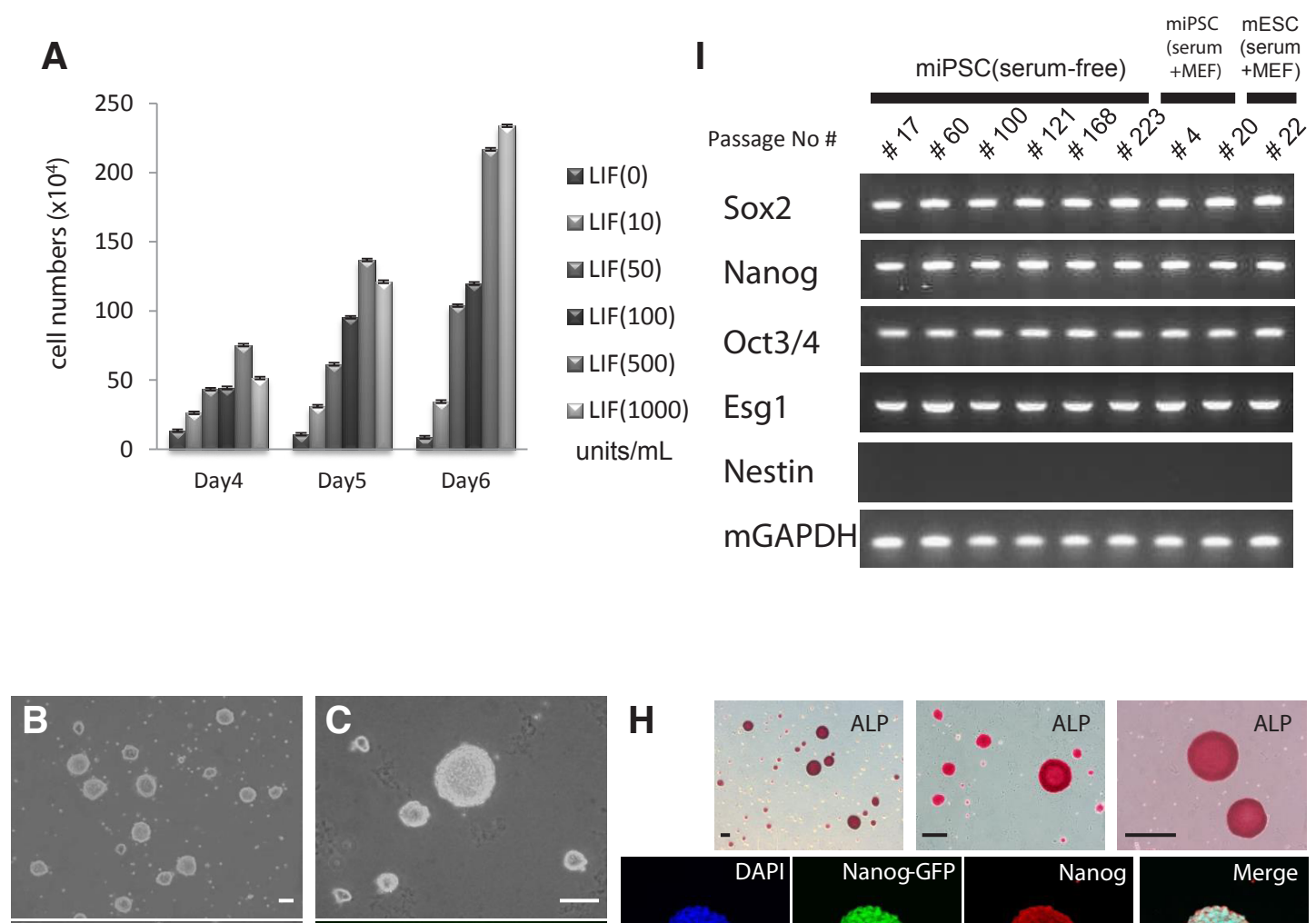

Fig. 1. Characteristics of mouse iPS cells cultured in ESF7. (A) The effect of leukemia inhibitory factor (LIF) on mouse iPS cell proliferation. The mouse iPS cells were seeded in 24-well plate at $2 \times 10^{3} \mathrm{cell} / \mathrm{s} /$ well in ESF7 or ESF6 (ESF7 minus LIF) (passage 32). These cells could not proliferate over a 6 day-period in ESF6. In the presence of LIF to the medium, significantly stimulated mouse iPS proliferation. Maximal growth stimulation of LIF were observed at 500 1000 units $/ \mathrm{ml}$. Undifferentiated cells increased in a LIF concentration dependent manner. Bars represent the mean \pm SEM. $(n=3)$. (B-G) Morphologies of mouse ES cells and iPS cells. (B-C) Mouse ES cell morphology cultured in ESF7 (Passage 315). (D-E) Mouse iPS cell morphology cultured in ESF7 (Passage 324). Phase contrast (left) and fluorescence (right) micrographs are shown. (F-G) Mouse iPS cell morphology cultured in CEM on MEFS (Passage 46). Phase contrast (left) and fluorescence (right) micrographs are shown. Barindicates 200 um. (H) Morphologies of mouse iPS cells cultured in ESF7and Pluripotency of iPS cells. (Upper panel) Stem cell marker expression: alkaline phosphatase (ALP) activity in mouse iPS cells cultured in ESF7 medium at passage 118. Bar indicates 200 um. (Lower panel) Stem cell marker expression: pluripotency marker expression in ESF7. These Cells were stained with anti-Nanog (Red), anti-Oct3/4 (Red), anti-SSEA-1 (Red). Nuclei were stained with DAPI (Blue). Nanog-GFP (Green) (passage 118) Bar indicates $50 \mathrm{\mu m}$. (I) The gene expression of pluripotency markers in mouse iPS cells. Expression of Sox2, Nanog, Oct3/4, Esg1, and Nestin was studied by RT-PCR analysis with total RNA isolated from iPS clones (APSO001) cultured in ESF7 at passages 17, 60, 100, 168, and 223 or in CEM on feeder cells at passages 4 and 20, and ES cells cultured in CEM on MEFs at passage 22. Primers for each marker gene only amplified endogenous gene sequences. 


\section{Results}

\section{Effects of LIF and serum on mouse iPS cell proliferation}

We first tested the ability of ESF7 medium (Furue et al., 2005), which we had developed for mouse ES cells, to support the proliferation of miPS cells. The cells (passage 32) were harvested in ESF7 or ESF6 (ESF7 minus LIF). miPS cells cultured in ESF6 did not proliferate over a 6 day-period. On the other hand, the addition of LIF to the medium significantly stimulated miPS cell proliferation (Fig. 1-A, passage 32). Undifferentiated cells increased in a LIF concentration dependent manner with maximal growth stimulation at $500 \sim 1000$ units/ml.

\section{Effects of culture conditions on mouse iPS cell morphology and expression of pluripotent stem cell markers}

When miPS cells (passage 324) were cultured in ESF7 medium on type I collagencoated flasks, the cells grew into densely packed colonies consistent with the cells

Fig. 2. The effect of growth factors with FGF-2 in mouse iPS cells. Differentiation induced from mouse iPS cells. The miPS cells were stimulated to differentiate by seeding on laminin-coated dishes in ESF5 in the presence of FGF-2 and heparin. Mouse iPS cell morphology cultured in ESF5 supplemented with FGF-2 (10 $\mathrm{ng} / \mathrm{ml})$ in ESF5 on laminin for 2, 4, and 6 days (Passage 93). Phase contrast (upper panel) and fluorescence (lower panel) micrographs were shown. Nanog-GFP positive cells were decreased day by day. Bar indicates 200 um. (B-H) Immunocytochemical staining of neural stem and neuronal cell markers. (B) anti-Nestin antibody, (C) anti- $\beta$-III tubulin antibody, (D) anti-MAP2 antibody, (E) antioligodendrocytes antibody, (F) anti-GFAP antibody, (G) anti-GABA antibody, (H) anti-keratin antibody. Nanog-GFP was also investigated. Nuclei were stained with DAPI. (Passage 118) Bar indicates 50 um. (I,J) RT-PCR analysis of neuronal stem and neuronal cell markers. We examined the effect of FGF-2 on neural marker gene expression in mouse iPS cells cultured in ESF5 on laminin for 6 days in adherent monolayer culture. These induced cells were positive for expression of Nestin, Otx-2 and AP-2. The effect of FGF-2 on neural marker gene expression in mouse iPS cells. The expression of neural and neural stem cell marker in mouse iPS cells cultured in ESF5 with FGF-2 $(10 \mathrm{ng} / \mathrm{ml})$ on laminin for 6 days. These expressions were nor malized to GAPDH mRNA. The values are mean $\pm \operatorname{SEM}(n=5) .{ }^{*}<0.01$ compared with Day 0. (K) Immunohistochemical analysis of mouse iPS cell derived embryoid bodies (EBs). Mouse iPS cells were transferred to low attachment 96 -well plates with ESF5 and FGF-2 (10 ng/ml) at a cell density of $5 \times 10^{3} \mathrm{cells} / \mathrm{well}$. After 14 days of floating culture, EBs were fixed in $4 \%(\mathrm{~W} / \mathrm{V})$ paraformaldehyde and embedded in paraffin. Sections were stained with hematoxylin, and for immunohistochemistry with antibodies to Nestin (1/100) and $\beta$-III tubulin (1/50). Positive and negative controls (NC) were used respectively, and sections were evaluated for intensity of stain (passage 79). Bar indicates $200 \mu \mathrm{m}$.

A
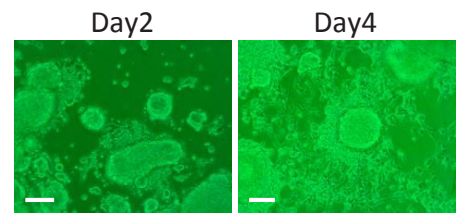

Day6

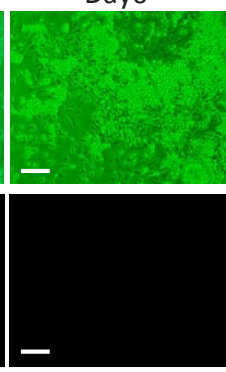

Nestin/Nanog/DAPI $\quad \beta$ III tubulin/Nanog/DAPI MAP2/Nanog/DAPI oligodendrocyte/Nanog/DAPI

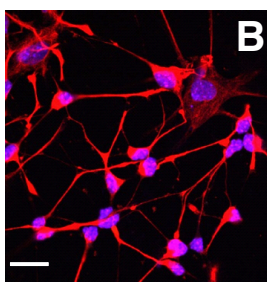

GFAP/Nanog/DAPI

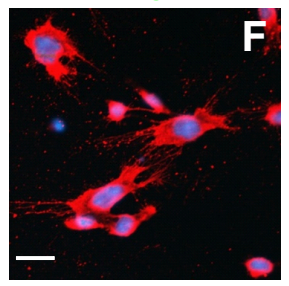

J

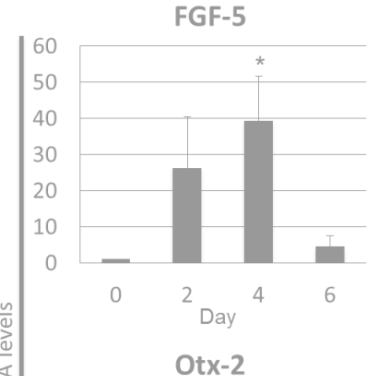

Otx-2

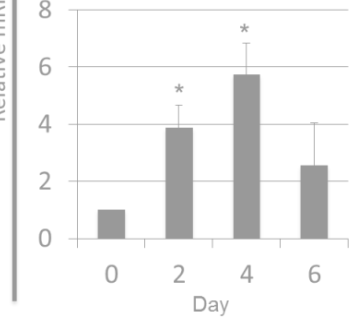

$\mathbf{K}$

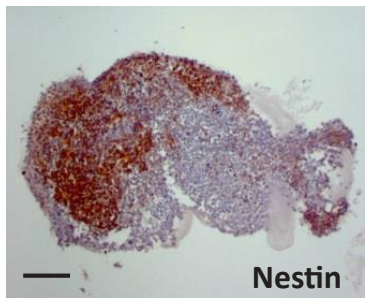

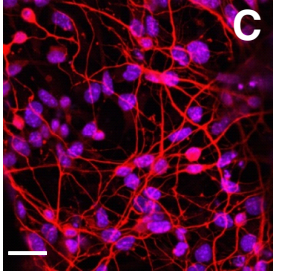

GABA/Nanog/DAPI

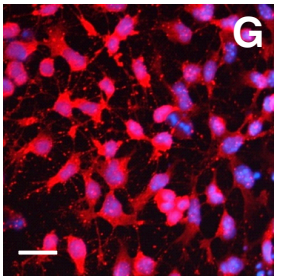

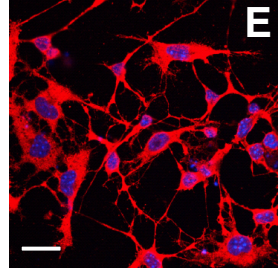

Keratin/Nanog/DAPI
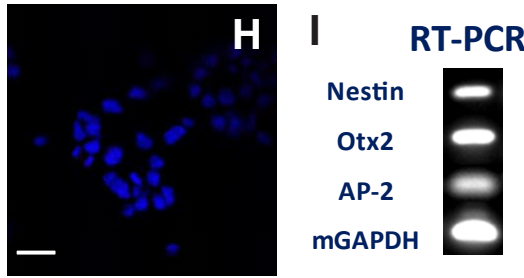

Musashi
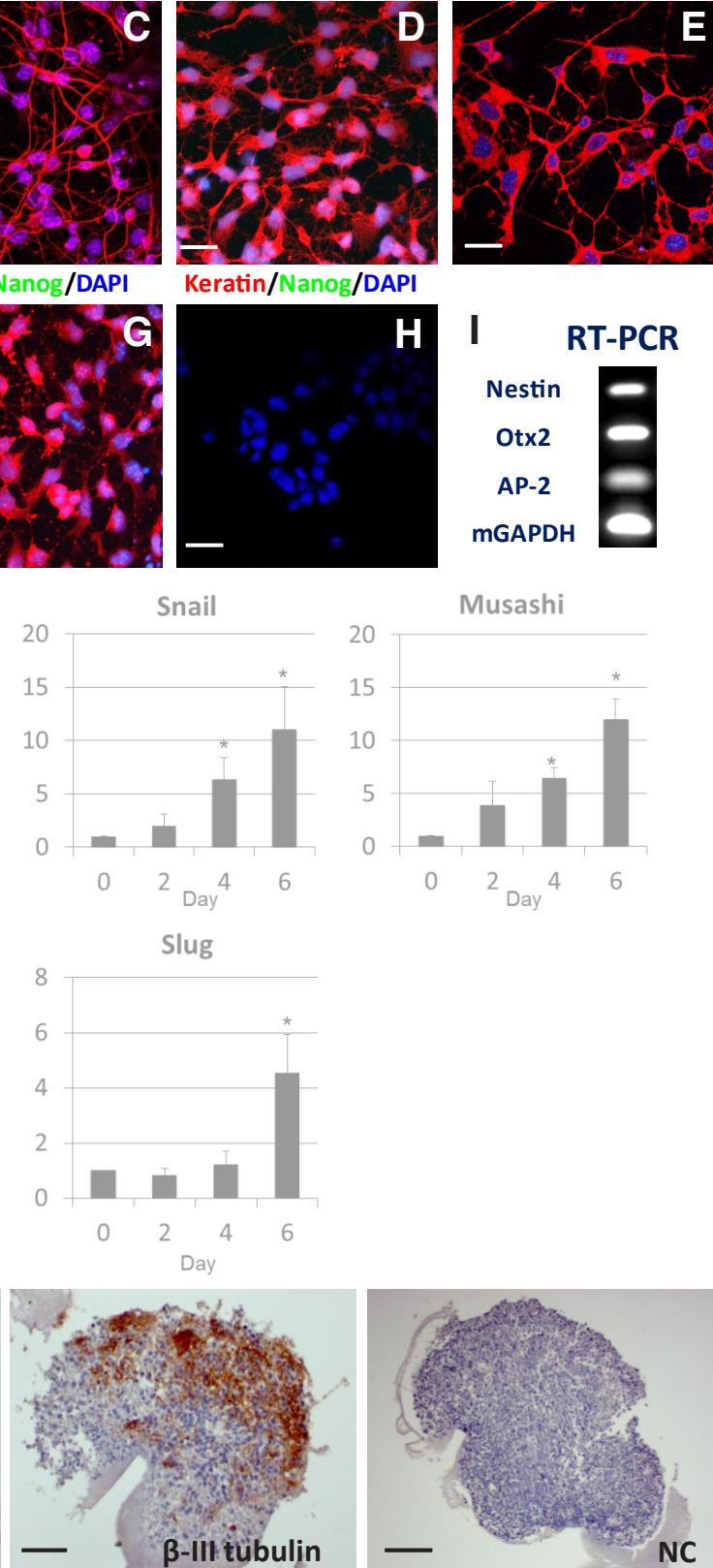

Snail
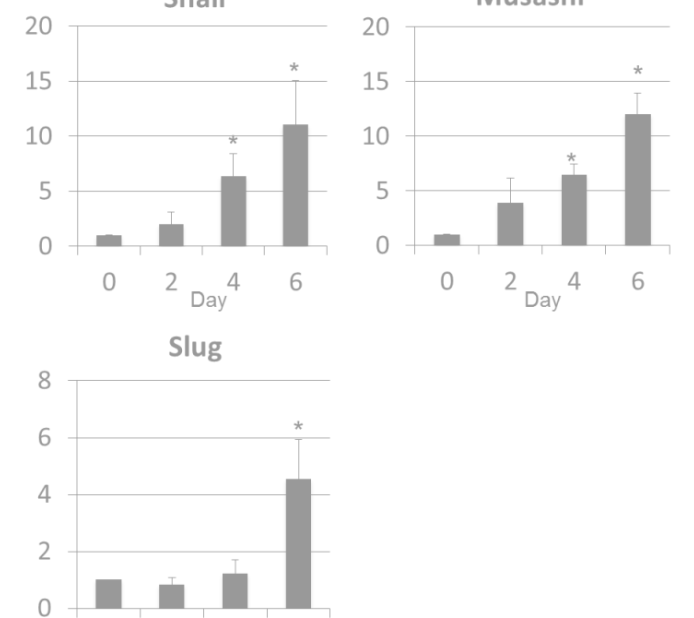

\section{西}

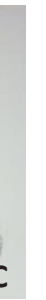


A

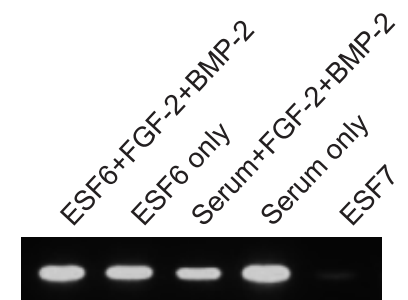

Nkx2.5

GATA4

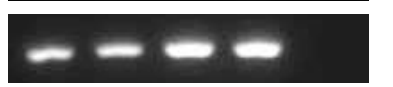

aMHC

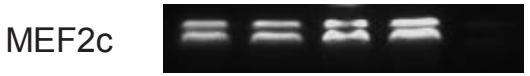

Oct3/4

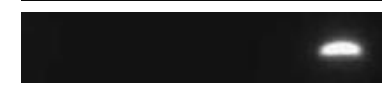

GAPDH
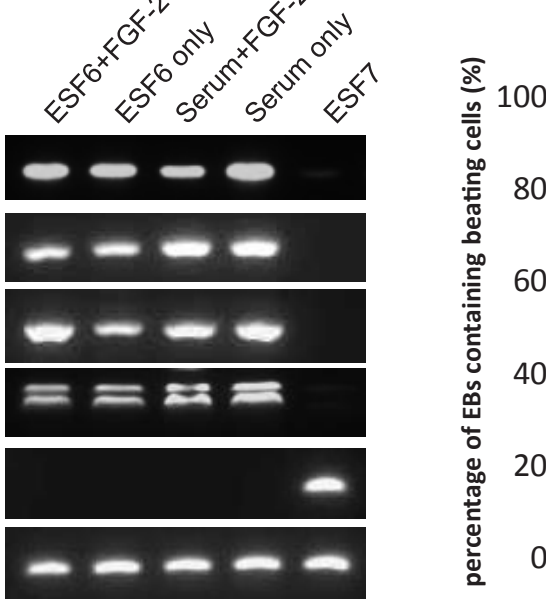

\section{Beating ratio of EBs}
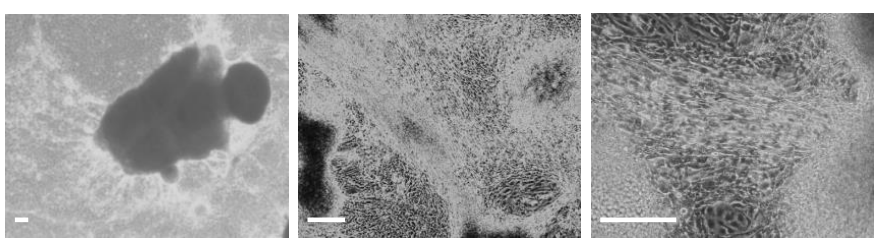

Culture days (d)

C

$$
0
$$

10

20

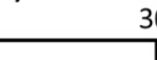

30
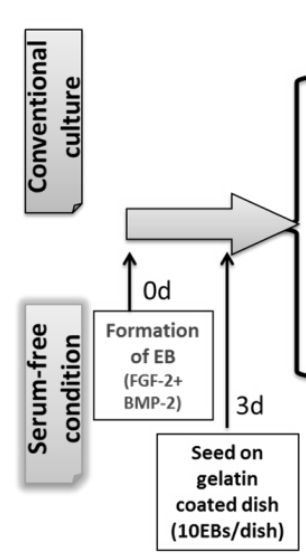

Phase contrast $\alpha$-Actinin/Nanog/DAPI

E
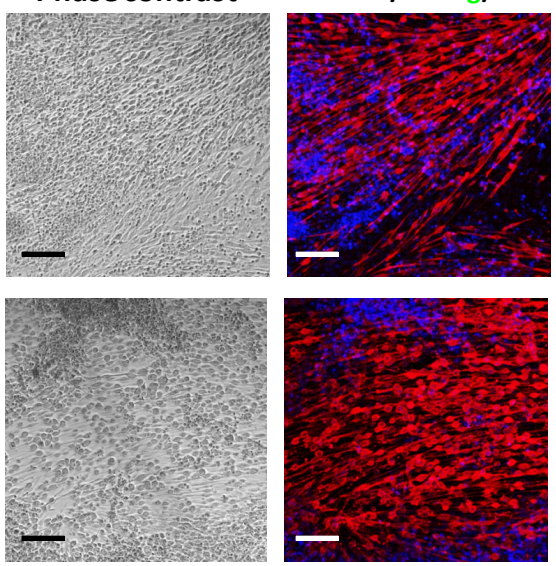

Phase contrast
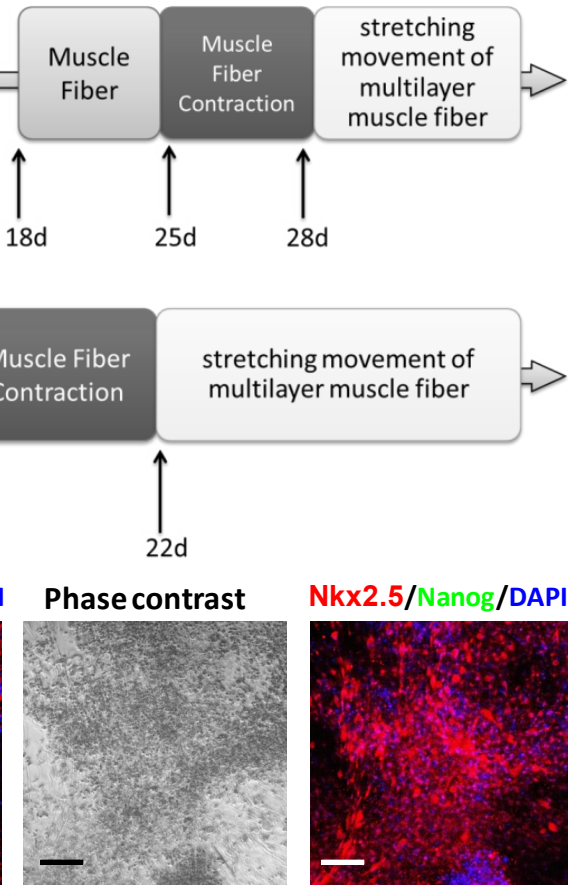

Muscle Fiber Contraction

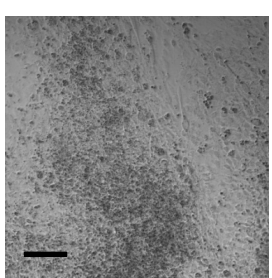

Nkx2.5/Nanog/DAPI

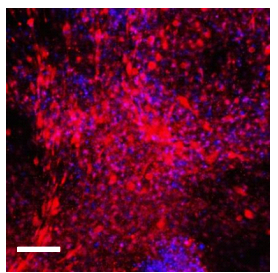

stretching movement of multilayer muscle fiber

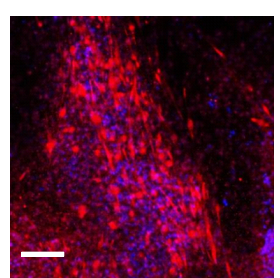

Fig. 3. Induction of cardiomyocytes with FGF-2 and BMP-2 from mouse iPS cells (A) RT-PCR analysis of cardiac and pluripotency gene expression. RT-PCR analysis of cardiac and pluripotency gene expression in cardiomyocytes differentiated mouse iPS cells on 30 days in culture. Nkx2.5, markergenes of cardiac progenitor and cardiomyocytes; GATA4, marker genes expressed in the adult vertebrate heart; $\alpha M H C$, marker genes for a representative sarcomeric protein; MEF2C, marker genes of heart precursor cells before formation of the linear heart tube; Oct3/4, marker genes of undifferentiated stem cell marker. (B) Gross morphology of a beating colony. Gross morphology of a beating colony from mouse iPS cells cultured in ESF6 with FGF-2 $(1 \mathrm{ng} / \mathrm{ml})$ and BMP-2 $(0.2 \mathrm{ng} / \mathrm{ml})$ after 18 days (Passage 54). Bar indicates 200 um. (C) Experimental schedule and time course of cardiomyocytes differentiation. Comparison of cardiomyocyte specific differentiation in serum-free medium and that in conventional serum supplemented medium. (D) The effect of growth factors on the beating ratio of EBs. To determine the optimal concentrations of FGF-2 and BMP-2 for efficient cardiomyogenic differentiation, several concentrations of FGF-2 $11 \mathrm{ng} / \mathrm{ml}, 2$ $\mathrm{ng} / \mathrm{ml}, 4 \mathrm{ng} / \mathrm{ml})$ and BMP2 $(0.2 \mathrm{ng} / \mathrm{ml}, 0.4 \mathrm{ng} /$ $\mathrm{ml}, 0.8 \mathrm{ng} / \mathrm{ml}$ ) were added to ESF6 medium on the same schedule. The most effective concentration of FGF-2 and BMP-2 was 2 $\mathrm{ng} / \mathrm{ml}$ and $0.4 \mathrm{ng} / \mathrm{ml}$, respectively. ESF6 only, ESF7 minus LIF; ESF6 +F2(1)+B2(0.2), ESF7 minus LIF with FGF-2 $(1 \mathrm{ng} / \mathrm{ml})$ and $B M P-2(0.2 \mathrm{ng} / \mathrm{ml}) ; E S F 6+F 2(2)+B 2(0.4)$, ESF7 minus LIF with FGF-2 $(2 \mathrm{ng} / \mathrm{ml})$ and $B M P-2(0.4 \mathrm{ng} / \mathrm{ml}) ; \quad E S F 6+F 2(4)+B 2(0.8)$, ESF7 minus LIF with FGF-2 $(4 \mathrm{ng} / \mathrm{m} /)$ and $B M P-2(0.8 \mathrm{ng} / \mathrm{mll}) ;$ Serum medium, CEM minus LIF; Serum+F2(1)+B2(0.2), CEM containing $15 \%$ FBS minus LIF with FGF-2 $(1 \mathrm{ng} / \mathrm{ml})$ and $B M P-2(0.2 \mathrm{ng} / \mathrm{ml})$. (E) $/ \mathrm{mmu}-$ nocytochemical staining of cardiomyocytespecific genes, $\alpha$-actinin and Nkx2.5. FGF-2 $(1 \mathrm{ng} / \mathrm{ml})$ and $B M P-2(0.2 \mathrm{ng} / \mathrm{ml})$ were added for 3 days during formation of EBs. The EBs on Day 18 were immunocytochemically stained with anti-actinin and anti-Nkx2.5 antibodies. Nuclei were visualized with DAPI and Nanog-GFP (Green) (Passage 54). Bar indicates $100 \mu \mathrm{m}$. 
retaining an undifferentiated ES-like morphology (Fig. 1 B-G, passage 324). The cells exhibited alkaline phosphatase activity, and expressed SSEA-1, Nanog and Oct3/4 (Fig. 1H, passage 118), and they expressed the undifferentiated ES cell-specific genes Sox2, Nanog, Oct3/4 and Esg1 as detected by RT-PCR (Fig. 1I). Moreover, these cells were maintained continuously and serially passaged for more than three years in ESF7 medium without feeder cells.

\section{Neuronal cell differentiation}

The miPS cells were stimulated to differentiate by seeding on laminin-coated dishes in ESF7 medium minus LIF and oleic acid-conjugated FAF-BSA (designated as ESF5), in the presence of FGF-2 and heparin. The cells with Nanog-GFP positive were decreased day by day (Fig. 2A, passage 93). These induced populations of cells were immunoreactive with antibodies to nestin (neural progenitor marker) (Fig. 2B, passage 118), to $\beta$-III tubulin (neural cell marker) (Fig. 2C, passage 118), to MAP2 antigen (neural cell marker) (Fig. 2D, passage 118), to oligodendrocyte cells (glial cell marker) (Fig. 2E, passage 118), to GFAP (astrocytes marker) (Fig. 2F passage 118), and to gamma- aminobutyric acid (GABA) (neural cell marker) (Fig. 2G, passage 118), but they did not react with an anti-keratin antibody or express Nanog-GFP (Fig. 2H, passage 118).

We next examined the effect of FGF-2 on neural marker gene expression in miPS cells cultured in ESF5 on laminin for 6 days in adherent monolayer culture. RT-PCR analysis was positive for expression of nestin, a neural stem cell marker, and the neural crest cell markers Otx-2 and AP-2 (Fig. 2I). Quantitative real-time PCR analysis showed an increased expression of Musashi1, which is a neural stem/progenitor cell marker, and increased expression of the neural crest marker genes Snail and Slug. Expression of a primitive ectoderm marker, neurotrophic factor, fibroblast growth factor (FGF)-5, and Otx-2, which may play a role in brain and sensory organ development, were also increased at 4 days. These results suggested that FGF-2 induced miPS cells to differentiate into neural progenitors after 4 days of culture (Fig. 2J). We also examined the effect of FGF-2 in embryoid body suspension culture. After 6 days in culture, sections of embryoid bodies were positively stained with both antibodies to Nestin and $\beta$-III tubulin (Fig. 2K, passage 79) suggesting that miPS cells maintained in ESF7 had the potential to differentiate into neuronal and glial cells. These results clearly revealed that mouse iPS cells maintained in ESF7 medium without feeder cells for more than 3 years could
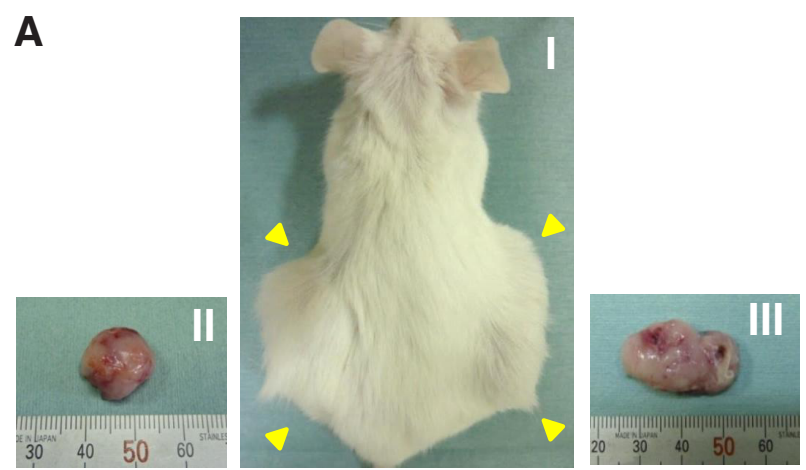

B

Fig. 4. Teratoma derived from mouse iPS cells. (A-I) mouse iPS cells cultured in serum- or serum-free conditions were suspended at $2 \times 10^{7} \mathrm{cell} / \mathrm{s} / \mathrm{ml}$ in PBS containing $0.15 \mathrm{mg} / \mathrm{m} /$ type I collagen. We injected 50 ul of the cell suspension $\left(1 \times 10^{6}\right.$ cells) subcutaneously into the dorsal flank of SCID mice (CB17//lcr-Prkdcscid/CrlCrlj). Fourweeks after the injection, tumors were surgically dissected from the mice. Teratomas were dissected and fixed in $4 \%$ paraformaldehyde. Samples were embedded in paraffin and processed with hematoxylin and eosin staining or Alcian Blue staining.(A-II): mouse iPS cells cultured in ESF7 (serum-free condition) were injected into the left side of the dorsal flank (passage 106).(A-III): mouse iPS cells cultured in conventional culture conditions (DMEM with 15\% FBS containing 1000 unit/m/ LIF) on MEF were injected into the right side of the dorsal flank (passage 78). (B) Histology of Teratomas. Paraffin-embedded teratomas from iPS cells cultured in ESF7 were sectioned, stained with hematoxylin and eosin photographed with ax 100 objective. All six mice formed tumors at 4 weeks post-injection. Control mice cultured in conventional serum supplemented medium also injected with $1 \times 10^{6}$, were also form teratomas. Various tissues present in teratomas derived from mouse iPS cells (Passage 106). (B-I) Hematoxylin and eosin staining. Neural tissue, epithelial cell (ectoderm), cartilage, muscle, adipose cell (mesoderm) and intestinal epithelium (endoderm) were observed. (B-II) Alcian Blue staining. Cartilage tissue, muscle tissue, adipose cells (mesoderm) and intestinal epithelium (endoderm) were observed. (B-III) Nestin and $\beta$-III tubulin staining. Positive immunostaining of Nestin and $\beta$-III tubulin confirming differentiation into neural tissues in teratomas. $\mathrm{NC}=$ negative control.
(I)
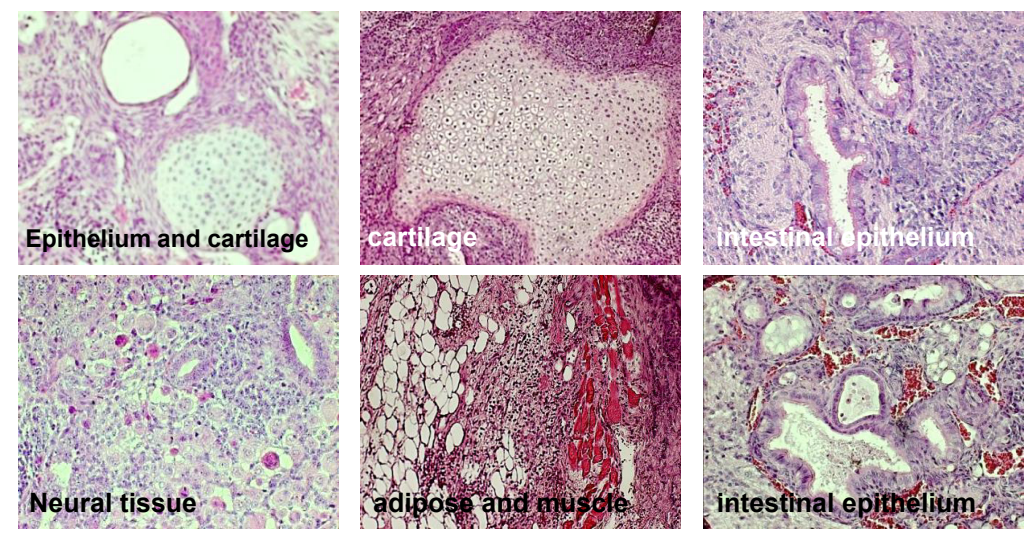

(II)
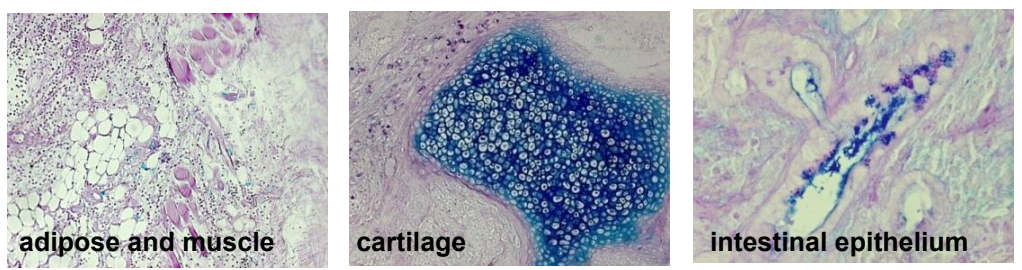

(III)
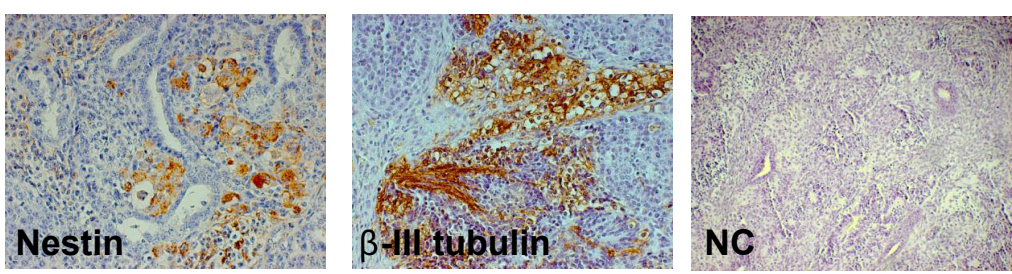
be induced by the addition or withdrawal of soluble growth factors and cytokines to differentiate along multiple cell lineages.

\section{Cardiomyocyte induction}

We found that FGF-2 with bone morphogenic protein 2 (BMP-2) induced miPS cells to differentiate into cardiomyocytes in embryoid body suspension culture. Previous studies showed that relatively low concentrations of FGF-2 or BMP-2 effectively enhanced the cardiomyogenic differentiation of miPS cells in serum-supplemented culture conditions (Kawai et al., 2004; Makino et al., 1999). To optimize culture conditions for cardiomyocyte differentiation, low concentration of FGF-2 (1 ng/ml, $2 \mathrm{ng} / \mathrm{ml}, 4 \mathrm{ng} / \mathrm{ml})$ and/or BMP-2 $(0.2 \mathrm{ng} / \mathrm{ml}, 0.4 \mathrm{ng} / \mathrm{ml}, 0.8 \mathrm{ng} / \mathrm{ml})$ were added to serum-supplemented or serum-free media. The expression levels of Nkx2.5, GATA4, MEF2C and $\alpha \mathrm{MHC}$ mRNAs at day 30 were examined by RT-PCR analysis (Fig. 3A). Nkx2.5 is a cardiac-specific homeobox gene. GATA4 is expressed in the adult vertebrate heart, as well as in yolk sac endoderm and cells involved in heart formation. The murine MEF2C is expressed in heart precursor cells before formation of the linear heart tube. $\alpha \mathrm{MHC}$ is a representative sarcomeric protein expressed in mature and differentiated cardiomyocytes. In serumfree culture conditions, smooth muscle fibers were observed at day 10 and beating cardiomyocytes observed at day 12 (Fig. 3B, passage 54) (Supplemental Video 1). These events occurred earlier than in conventional serum- supplemented conditions. Furthermore, the ratio of beating cardiomyocytes in serum-free medium was higher than these in serum-supplemented medium (Fig. 3C). For cardiomyogenic differentiation the most effective concentration of FGF-2 and BMP-2 was $2 \mathrm{ng} / \mathrm{ml}$ and $0.4 \mathrm{ng} / \mathrm{ml}$, respectively (Fig. 3D). To confirm the cardiomyogenic differentiation of miPS cells, miPS cell clusters were immunocytochemically stained with anti-actinin, a representative cardiomyocytes specific sarcomeric protein, together with anti-Nkx2.5 antibodies (Fig 3E, passage 118). Contracting clusters of miPS cells on day 11 were specifically stained with both antibodies, suggesting that the majority of the contracting miPS cells exhibited the features of cardiomyocytes. In addition, cells positive for cardiomyocyte markers appeared earlier than they did in serum-containing cultures.

\section{Teratoma formation assay}

miPS cells cultured under serum-free or conventional serumsupplemented conditions were suspended and injected (1 $\times 10^{6}$ cells) subcutaneously into the dorsal flank of severe combined immunodeficient (SCID) mice. Four weeks after injection, tumors were surgically dissected from the mice, weighed, fixed in PBS containing $4 \%$ formaldehyde, and embedded in paraffin. Sections were stained with hematoxylin and eosin and Alcian Blue. Histological analysis demonstrated that the formed tumors contained tissues derived from all three embryonic germ layers $(n=6)$ (Fig. 4A, passage 106). Epithelial tissues, neural issues (ectoderm), muscle and cartilage (mesoderm) and intestinal epithelial tissues (endoderm) were identified histologically in the miPS cell-derived teratomas (Fig. 4B, passage 106).

\section{Karyotype analysis and long-term stability}

Almost all of the miPS cells maintained in serum-free conditions using ESF7 had a normal karyotype (Supplemental Fig. 1- (i) passage 195). All of the cells retained ability to express stem cell markers, and they remained pluripotent as demonstrated by teratoma formation after prolonged culture (Supplemental Fig. 1- (ii) passage 195).

\section{Germ-line transmission of miPS cell cultured in serum-sup- plemented or serum-free condition}

We examined the ability of miPS cells cultured in both serumsupplemented and serum-free conditions to produce adult chimaeric mice. We injected 2-20 male miPS cells into C57/BL6 blastocysts or 8-cells, which we transplanted into uteri of pseudo-pregnant mice. We tried several times using high passage or low passage cells cultured in serum-free or serum-supplemented medium. However we did not obtained any adult chimaeras from embryos injected with miPS cells passaged in the presence or absence of fetal bovine serum.

\section{Discussion}

We previously reported a simple serum-free culture system that maintained mouse ES cells in an undifferentiated state without feeder cells (Furue et al., 2005). In this study, we have successfully adapted the system to maintain the proliferation, self-renewal and pluripotency of mouse iPS cell without feeder cells for more than three years. As this serum-free adherent monoculture system supports the long-term propagation of pluripotent iPS cells in vitro, it will allow us to elucidate the cell responses to growth factors and other stimuli under defined conditions, and it could provide information to further understand molecular mechanisms operating during early development in vivo.

Until quite recently mouse ES and iPS cells were commonly maintained on primary embryonic fibroblast feeder cells in culture medium supplemented with serum and leukemia inhibitory factor (LIF) (Chung et al., 2005; Takahashi et al., 2006; Takahashi et al., 2007; Okita et al., 2007; Kaufman et al., 1983; Martin, 1981; Doetschman et al., 1985). Previous studies demonstrated that self-renewal and pluripotency could be maintained under these culture conditions (Smith et al., 1988). In the absence of LIF, iPS cells differentiate spontaneously in serum-containing culture medium. Culture protocols have been developed recently that permit the derivation of some types of cells from undifferentiated ES and iPS cells. However, because these procedures require the cultivation of ES and iPS cell aggregates, conditioned medium containing undefined components or feeder cells, they produce variable and heterogeneous results (Lake et al., 2001; Todaro and Green, 1963). Moreover, these cells usually become karyotypically abnormal during the course of serial cultivation (Todaro and Green, 1963; Loo et al., 1987). These effects may be caused by undefined or unknown growth factors and differentiation factors in serum or feeder cell-conditioned medium such as EGF, FGFs, activin A, and PDGF (Doetschman et al., 1985; Todaro and Green, 1963; Loo et al., 1987). Thus it is very important to standardize culture procedures with defined culture conditions (serum-free and feeder-free defined culture conditions). We previously confirmed that LIF had little influence on cell proliferation of ES-D3 cells in serum-supplemented medium, however, in ESF7 medium, LIF was essential for the mouse ES-D3 survival, and it clearly stimulated cell proliferation in a concentration-dependent manner. In this study, we confirmed the same result in miPS cells that LIF is essential for the miPS cell survival and stimulated cell proliferation in serumfree and feeder-free culture condition. Previous work by others 
has shown that activation of LIF/STAT3 (Smith et al., 1988; Niwa et al., 1998; Matsuda et al., 1999; Yang et al., 2010), and BMP/ SMAD/Id signaling pathways (Ying et al., 2003; Brandenberger et al., 2004) is necessary for mouse ES cells to maintain pluripotency. Using pathway inhibitors it has been found that Jak-Stat3, PI3KAkt, and MAPK are located at the downstream of LIF signaling pathway. PI3K-Akt and MAPK pathways are regulated by a number of factors whereas the Jak-Stat3 pathway is only regulated by LIF (Yang et al., 2010; Kunath et al., 2007; Silva et al., 2008; Ying et al., 2008). The simple serum-free culture condition described here consists of known components and can be used to identify and characterize the effects of undefined as well as defined factors in miPS cell biology.

When miPS cells were seeded on laminin-coated dishes, the cells differentiated into primitive ectoderm even in the presence of LIF, while type I collagen supported the undifferentiated state of the cells (Hayashi et al., 2007). During development, cells require a proper environment for proliferation, differentiation and apoptotic cell death, and the present findings suggest that our defined culture condition could mimic environments for cell differentiation in early development in vivo. Neural crest markers are first expressed in the primitive ectoderm and are also expressed in emerging neural crest cells (Eckert et al., 2005). FGF-2 induces neural cell differentiation from mouse ES cells (McKay, 1997). We have also shown that FGF-2 induces neural crest marker positive cells from mouse ES cells at high frequency in a defined serum-free medium (Furue et al., 2005). This study reveals that in ESF5 medium an appropriate concentration of FGF-2 promotes differentiation of miPS cells from neural progenitor cells into peripheral neuronal cells, glial cells and migrating cranial neural crest cells. In addition, these cells expressed Otx-2 and AP-2, which are related to neural crest and craniofacial development. Thus, with our growth factor defined serum-free culture system miPS cell differentiation may be used to study the role of neural crest development in cranio- and maxillo-facial development.

BMP-2 and FGF-2 play important roles in the early cardiomyogenic differentiation of miPS cells. Recent studies have shown that both BMP-2 and FGF-2 play an important role in early heart development, especially in the induction of the mesoderm component at the time of the formation of the three embryonic germ layers (Shimoji et al., 2010; Yuasa et al., 2005). In the present experimental protocol, this stage may correspond to the first three days of embryoid body formation. Other studies have reported cardiomyocyte differentiation in spheroid cultures with fetal bovine serum or various inhibitors and hormones (Shimoji et al., 2010; Yuasa et al., 2005; Fujiwara et al., 2011; Hao et al., 2008; Olson et al., 2003; Pandur et al., 2002). This is a novel protocol to successfully elicit in vitro cardiomyogenic differentiation of miPS cells under defined serum-free culture conditions using FGF-2 and BMP-2. Using this method, we observed cardiac smooth muscle fibers and beating cardiomyocytes. Cells positive for cardiomyocyte markers appeared earlier than they did in serum-containing cultures. This observation suggests that the medium supplemented with serum might contain unknown factors that inhibit cardiomyogenic differentiation of miPS cells, and that the population of cells cultured in serum-free conditions was more homogeneous than that of cultured in conventional serum- supplemented conditions. As a result, this study describes a novel protocol to induce miPS cell differentiation into beating cardiomyocytes. This novel protocol to induce beating cardiomyocytes will be useful for drug screening and developing treatments for cardiovascular diseases.

The identification and isolation of a cardiac precursor cell population is expected to provide a source of cells for tissue regeneration while also providing valuable insight into cardiac development.

A recent study focused on identifying these progenitor cells and elucidating signaling mechanisms involved. This study reported Smad and Wnt signaling pathways are important in stem cell fate determination and their commitment to cardiovascular differentiation (Yuasa et al., 2005). Also, cardiomyogenic signals such as BMP and FGF activate the expression of cardiac specific transcription factors such as homeodomain protein Nkx2.5. Nkx2.5 activates a number of downstream transcription factors such as MEF2C and GATA-4, which activate the expression of cardiac muscle specific proteins (Fujiwara et al., 2011). In this study exposure of miPS cells to BMP-2 and FGF-2 without LIF for only 3 days during embryoid body formation led to efficient cardiomyogenic differentiation. This period may correspond to the time between embryonic E4 and E6, when the three embryonic germ layers are being formed. These data suggest that co-operative effects of FGF-2 and BMP-2 may play crucial roles in the induction of early stage cardiomyogenic differentiation in vitro.

We examined the ability of miPS cells cultured in both serumsupplemented and serum-free conditions to produce adult chimeric mice. Because the passaged cells did not contribute to chimeras, we tested the cells obtained from Riken Bio Resource Center without prolonged cultivation and they did not form chimeras either. Thus we concluded that the loss of chimera forming potential was likely not the result of passaging in serum-free and feeder-free medium.

As this simple serum-free adherent monoculture system supports the long term propagation of pluripotent iPS cells in vitro, it will allow us to elucidate cellular responses to various environmental stimuli under defined conditions, and it will provide useful information for the development of feeder-free and serum-free medium for human iPS cells. In this culture system the effects of exogenous factors can be analyzed without the confounding influence of undefined components. This methodology could be used to study the mechanisms underlying early embryonic development and to assist in the development of in vitro developmental toxicity assays.

\section{Materials and Methods}

\section{Maintenance of mouse iPS cells}

The mouse iPS cell (miPS) line iPS-MEF-Ng-20D-17 (Okita et al., 2007) (APS0001: Riken Bio Resource Center, Japan : passage number 11) was routinely maintained in ESF7 medium (Furue et al., 2005) in $25 \mathrm{~cm}^{2}$ plastic flasks (Corning, New York) coated with $0.15 \mathrm{mg} / \mathrm{ml}$ type I collagen (Nitta gelatin, Osaka, Japan) in a humidified of $5 \% \mathrm{CO}_{2}$ at $37{ }^{\circ} \mathrm{C}$. This mouse iPS cell line expresses green fluorescent protein (GFP) under the control of the Nanog promoter.

ESF7 medium is composed of ESF basal medium (Cell Science and Technology Institute, Miyagi, Japan) (Furue et al., 2005) supplemented with seven defined factors (Bottenstein et al., 1979; Sato et al., 1987; Sato et al., 2010): insulin $(10 \mu \mathrm{g} / \mathrm{ml})$, transferrin $(5 \mu \mathrm{g} / \mathrm{ml}), 2$-aminoethanol (10 $\mu \mathrm{M})$, 2-mercaptoethanol $(10 \mu \mathrm{M})$, sodium selenite $(20 \mathrm{nM})$, oleic acid (4.7 $\mu \mathrm{g} / \mathrm{ml}$ ) conjugated with fatty acid-free bovine serum albumin (FAF-BSA), and 1000 units $/ \mathrm{ml} \mathrm{leukemia} \mathrm{inhibitory} \mathrm{factor} \mathrm{(ESGRO}{ }^{\circledR}$, Millipore, Billerica, MA), as described previously (Furue et al., 2005). Mouse iPS cells were harvested in $0.001 \%$ trypsin- $0.01 \%$ ethylenediaminetetraacetic acid (EDTA) in $\mathrm{Ca}^{2+}$ and $\mathrm{Mg}^{2+}$-free phosphate-buffered saline (PBS), and the trypsin was inactivated with $0.1 \%$ soybean trypsin inhibitor (Sigma, St. Louis, MO) in 
PBS. These cells were reseeded at $2 \times 10^{5}$ cells in a type I collagen-coated $25-\mathrm{cm}^{2}$ flasks (Corning, Coming, NY). These cells were subcultured every 2-3 day (Furue et al., 2005; Hayashi et al., 2007).

As a control, miPS cells were maintained on feeder layers of mitomycin C-treated mouse embryonic fibroblasts (ReproCELL, Yokohama, Japan) in Complete ES medium (CEM): Dulbecco's modified Eagle's medium supplemented with $15 \%$ fetal bovine serum (FBS), $4 \mathrm{mM}$ L-glutamine, $0.1 \mathrm{mM}$ 2-mercaptoethanol (2-ME), $1.5 \mathrm{~g} / \mathrm{L}$ sodium bicarbonate, and 1000 unit/ml LIF (Millipore) (Smith et al., 1988; Dulbecco and Freeman, 1959; Doetschman et al., 1985; Pandur et al., 2002; Williams et al., 1988).

\section{Cell proliferation}

To investigate LIF for mitogenic activity on iPS cells at various passage numbers the cells were seeded in a type I collagen-coated 24-well plate (Becton Dickinson, Franklin Lakes, $\mathrm{NJ}$,) at a cell density of $2 \times 10^{3}$ cells/ well in ESF7 without LIF. Increasing concentrations of LIF $(10,50,100$, $500,1000 \mathrm{unit} / \mathrm{mL}$ ) were added to each well, and the cells were cultured at $37^{\circ} \mathrm{C}$ in a humid atmosphere of $5 \% \mathrm{CO}_{2}$ Cell numbers in triplicate wells were counted daily with a Coulter particle counter (Beckman Coulter, Hialeah, FL).

\section{Alkaline phosphate (ALP) staining}

The cells plated on type I collagen-coated dishes in ESF7 medium were cultured for 6 days with medium renewal every 2 day. Alkaline phosphatase (ALP) activity in the cells was detected using a Fast Red substrate kit (Nichirei Biosciences, Tokyo, Japan), as described by Toumadje et al.

\section{Antigen expression (Immunocytochemistry)}

To detect pluripotent stem cell marker antigens, cells were cultured under the conditions described above and fixed in $4 \%$ (w/v) paraformaldehyde. Fixed cells were stained with a mouse anti-SSEA-1 antibody (1/100 dilution) (Stemgent ${ }^{\circledR}$, Cambridge, MA). To detect the intracellular antigen Oct-3/4 (1/100 dilution) (Beckton Dickinson) and Nanog (1/100 dilution) (Santa Cruz Biotechnology, Santa Cruz, CA), fixed cells were permeabilized with $0.2 \%$ TritonX-100 and then stained with primary antibodies. These primary antibodies were visualized with Alexa Fluor ${ }^{\circledR}$ 594-conjugated goat anti-rabbit IgG or Alexa Fluor ${ }^{\circledast}$ 594-conjugated rabbit anti-mouse IgG (Invitrogen, Carlsbad, CA). After washing, these cells were stained with DAPI. Fluorescence images were acquired using a Zeiss inverted LSM confocal microscope (Carl Zeiss, GmbH, Germany).

\section{Gene expression}

A detailed reverse transcription-polymerase chain reaction (RT-PCR) protocol was described previously (Furue et al., 2005). Briefly, total RNA was extracted from iPS cells using the RNA spin mini isolation kit (GE Healthcare UK Ltd), according to manufacturer's instructions. cDNA was synthesized from $1 \mu \mathrm{g}$ of total RNA using High capacity RNA-to cDNA master mix (Applied Biosystems, Carlsbad, CA). RT-PCR was performed with AmpliTaq Gold DNA polymerase with Gene Amp (Applied Biosystems). The primers and reaction conditions used are described in Supplementary Table1. PCR products were size-fractionated using 1.5\% agarose gel electrophoresis. DNA markers were used to confirm the size of the fragments.

\section{In vitro cell differentiation into neuronal cells}

For monolayer culture, miPS cells were seeded by treating with trypsinization. These miPS cells were transferred to laminin $\left(2 \mu \mathrm{g} / \mathrm{cm}^{2}\right.$, Sigma) coated 24-well plates at a cell density of $1 \times 10^{4}$ cells/ well in ESF5 (ESF7 medium minus LIF and oleic acid-conjugated FAF-BSA) with FGF-2 (10ng/ $\mathrm{ml}$ (R\&D systems) and heparan sulfate (100 ng/ml) (Sigma Aldrich), for 2days. After induction, medium changed in ESF5 (without BSA-oleic) with heparin for another 4 days (Aihara et al., 2010).

These cells were stained with anti-Nestin monoclonal antibody $(1 / 400$ dilution) (American Research Products Inc., Waltham, MA), anti- $\beta$-III tubulin monoclonal antibody (1/200 dilution) (Millipore), anti-MAP2 antibody (1/400 dilution) (Millipore), anti-oligodendrocyte antibody (1/400 dilution) (clone 81, Millipore), anti-GFAP antibody (Dako Cytomation, Glostrup, Denmark), anti-GABA antibody (1/400 dilution) (Millipore) along with 4',6-diamidino-2-phenylindole (Sigma). These primary antibodies were visualized with Alexa Fluor $594^{\circledR}$-conjugated goat anti-rabbit IgG or Alexa Fluor $594^{\circledR}$-conjugated rabbit anti-mouse IgG (Invitrogen).

Total RNA derived from plated cells on days 2, 4 , and 6 was used for quantitative RT-PCR analysis. Quantitative RT-PCR was performed using Brilliant III Ultra-Fast SYBR Green QPCR Master Mix (Agilent Technologies, Santa Clara,CA) according to manufacturer's directions with a Stratagene Mx 3000P system (Stratagene, La Jolla, CA). The sequences of the primers are listed in Supplemental Table1. The relative expression of mRNAs was calculated and compared with the expression in each control.

For Embryoid body (EB) formation, miPS cells were harvested by treating with trypsinization. The clumps of the cells were transferred to low attachment 96 -well plates with ESF5 and FGF-2 $(10 \mathrm{ng} / \mathrm{ml})$ and heparin sulfate $(100 \mathrm{ng} / \mathrm{ml})$ at a cell density of $5 \times 10^{3}$ cells $/$ well. After 2 days in suspension culture, EBs were transferred to 24-well low attachment plates and cultured in ESF5 with heparin for another 12 days. The medium was changed every other day. Embryoid bodies were fixed in $4 \%(\mathrm{w} / \mathrm{v})$ paraformaldehyde and embedded in paraffin. Sections were stained with hematoxylin, and for immunohistochemistry with Nestin (1/100 dilution) and $\beta$-III tubulin (1/50 dilution). Positive and negative controls were used respectively, and sections were evaluated for intensity of stain.

\section{In vitro cell differentiation into cardiomyocytes}

To initiate the differentiation, miPS cells were cultured in ESF6 with FGF-2 (1 ng/ml, $2 \mathrm{ng} / \mathrm{ml}$, or $4 \mathrm{ng} / \mathrm{ml})$ (R\&D Systems, Minneapolis, MN) and BMP-2 (0.2 ng/ml, $0.4 \mathrm{ng} / \mathrm{ml}$, or $0.8 \mathrm{ng} / \mathrm{ml})$ (R\&D Systems) at a cell density of $1 \times 10^{4}$ cells/well in 96 well low attachment plates. After 3 days in suspension, the EBs were transferred to gelatin-coated $35-\mathrm{mm}$ cell culture dishes at a density of 10-20 EBs per dish with ESF6 medium only, and cultured for an additional 30 days. The medium was changed every other day. The ratio of beating embryoid bodies was calculated (Kawai et al., 2004; Makino et al., 1999).

Differentiated iPS cells on days 11 were fixed in $4 \%(\mathrm{v} / \mathrm{w})$ paraformaldehyde and permeabilized with $0.2 \%$ Triton $X-100$. These cells were stained with anti $\alpha$-actinin (1/400 dilution) (Sigma-Aldrich) or anti-Nkx2.5 (1/300 dilution) (GeneTex, Irvine, CA) along with 40-6-diamidino-2-phenylindole (Sigma). The primary antibodies were visualized with Alexa Fluor 594-conjugated goat anti-rabbit IgG or Alexa Fluor 594-conjugated rabbit anti-mouse IgG (Invitrogen). Total RNA was extracted from differentiated iPS cells on days 30 . The primers used are described in Supplemental Table1. PCR products were size-fractionated using $1.5 \%$ agarose gel electrophoresis. DNA markers were used to confirm the size of the fragments.

\section{Teratoma formation assay and histological analysis}

These miPS cells cultured in serum-supplemented or serum-free conditions were suspended at $2 \times 10^{7}$ cells $/ \mathrm{ml}$ in PBS containing 0.15 $\mathrm{mg} / \mathrm{ml}$ type I collagen. We injected $50 \mathrm{ul}$ of the cell suspension $\left(1 \times 10^{6}\right.$ cells) subcutaneously into the dorsal flanks of 6 SCID (CB17/lcr-Prkdcscid) $\mathrm{CrICrlj)} \mathrm{mice.} \mathrm{Four} \mathrm{weeks} \mathrm{after} \mathrm{the} \mathrm{injection,} \mathrm{tumors} \mathrm{were} \mathrm{surgically} \mathrm{dis-}$ sected from the mice. Samples were weighed, fixed in PBS containing $4 \%$ formaldehyde, and embedded in paraffin. Sections were stained with hematoxylin and eosin and Alcian Blue stain.

\section{Karyotype analysis} ence).

Karyotype analysis has performed with G-band staining (insert refer-

\section{Germ-line transmission of miPS cell cultured in serum-free condition}

We examined the ability of miPS cells cultured in both serumsupplemented and serum-free conditions to produce adult chimaeras. For micromanipulation, miPS cells were trypsinized and suspended in ESF7 or conventional serum medium (Sasaki et al., 2009; Kanda et al., 
2012). Then, we injected $2-20$ male miPS cells into C57/BL6 blastocysts or 8-cells, which we transplanted into uteri of pseudo-pregnant mice.

\section{Ethics statement}

All animal experiments in this study strictly followed a protocol approved by the Institutional Animal Care and Use Committee of Hiroshima University (approval number: A-10-92, A-10-03).

\section{Acknowledgments}

The authors congratulate Dr. Shinya Yamanaka for sharing in the 2012 Nobel Prize in Physiology or Medicine. This work was supported in part by a research grant (no. 22659369) from the Japanese Ministry of Education, Culture, Sports, Science and Technology to T. O.

\section{References}

AIHARA, Y., HAYASHI, Y., HIRATA, M., ARIKI, N., SHIBATA, S., NAGOSHI, N., NAKANISHI, M., OHNUMA, K., WARASHINA, M., FURUE, M. K. et al. (2010). Induction of neural crest cells from mouse embryonic stem cells in a serum-free monolayer culture. Int J Dev Biol. 54: 1287-1294.

BOTTENSTEIN, J. E. and SATO, G. H. (1979). Growth of a rat neuroblastoma cell line in serum-free supplemented medium. Proc. Natl Acad. Sci USA 76: 514-517.

BRANDENBERGER, R., WEI, H., ZHANG, S., LEI, S., MURAGE, J., Fisk, G. J., Li ,Y., Xu, C., FANG, R., GUEGLER, K., RAO, M. S., MANDALAM, R., LEBKOWSKI, J. and STANTON, L. W. (2004). Transcriptome characterization elucidates signaling networks that control human ES cell growth and differentiation. Nat Biotechnol. 22: 707-71

CHUNG, Y., KLIMANSKAYA, I. and LANZA, R. (2005). Embryonic and extraembryonic stem cell lines derived from single mouse blastomeres. Nature 439: 216-219.

DOETSCHMAN, T. C., EISTETTER, H., KATZ, M., SCHMIDT, W. and KEMLER, R. (1985). The in vitro development of blastocyst-derived embryonic stem cell lines: formation of visceral yolk sac, blood islands and myocardium. J Embryol Exp Morphol. 87: 27-45.

DULBECCO, R. and FREEMAN, G. (1959). Plaque production by the polyoma virus. Virology $8: 396-397$.

ECKERT, D., BUHL, S., WEBER, S., Jäger, R. and SCHORLE, H. (2005). The AP-2 family of transcription factors. Genome Biol 6: 246 .

FUJIWARA, M., YAN, P., OTSUJI, T. G., NARAZAKI, G., UOSAKI, H., FUKUSHIMA, H., KUWAHARA, K., HARADA, M., MATSUDA, H., YAMASHITA, J. K. et al. (2011). Induction and enhancement of cardiac cell differentiation from mouse and human induced pluripotent stem cells with cyclosporin-A. PLoS One. 6: e16734.

FURUE, M., OKAMOTO, T., HAYASHI, Y., OKOCHI, H., FUJIMOTO, M., MYOISHI, Y., ABE, T., OHNUMA, K., SATO, G. H., ASASHIMA, M. and SATO, J. D. (2005). Leukemia inhibitory factor as anti-apoptotic mitogen for pluripotent mouse embryonic stem cells in a serum-free medium without feeder cells. In Vitro Cell Dev Biol Animal 41: 19-28.

HAO, J., DALEO, M. A., MURPHY, C. K., YU, P. B., HO, J. N., HU J., PETERSON, R. T., HATZOPOULOS, A. K. and Hong, C. C. (2008). Dorsomorphin, a selective small molecule inhibitor of BMP signaling, promotes cardiomyogenesis in embryonic stem cells. PLoS One. 3: e2904.

HAYASHI, Y., FURUE, M. K., OKAMOTO, T., OHNUMA. K., MYOISHI, Y., FUKUHARA, Y., ABE, T., SATO, J. D., HATA, R. and ASASHIMA, M. (2007). Integrins regulate mouse embryonic stem cell self-renewal. Stem Cells 25: 3005-3015.

KANDA, A., SOTOMARU, Y., SHIOZAWA, S. and HIYAMA, E. (2012). Establishment of ES cells from inbred strain mice by dual inhibition (2i). J Reprod Dev 58: 77-83.

KAUFMAN, M. H., ROBERTSON, E. J., HANDYSIDE, A. H. and EVANS, M. J. (1983). Establishment of pluripotential cell lines from haploid mouse embryos. J Embryol Exp Morphol. 73 : 249-261.

KAWAI, T. TAKAHASHI, T., ESAKI, M., USHIKOSHI, H., NAGANO, S., FUJIWARA. H. and KOSAI, K. (2004). Efficient Cardiomyogenic Differentiation of Embryonic Stem Cell by Fibroblast Growth Factor 2 and Bone Morphogenic Protein 2. Circ J. $68: 691-702$

KUNATH, T., Saba-EI-Leil M. K., ALMOUSAILLEAKH, M., WRAY, J., MELOCHE, S. and SMITH, A. (2007). FGF stimulation of the Erk1/2 signaling cascade triggers transition of pluripotent embryonic stem cells from self-renewal to lineage commitment. Development 134: 2895-2902
LAKE, J., RATHJEN, J., REMISZEWSKI, J. and RATHJEN PD. (2001). Reversible programming of pluripotent cell differentiation. J Cell Sci. 113: 555-566.

LOO, D. T., FUQUAY, J. I., RAWSON, C. L. and BARNES, D. W. (1987). Extended culture of mouse embryo cells without senescence: inhibition by serum. Science 236: 200-202

MAKINO, S., FUKUDA, K., MIYOSHI, S., KONISHI., F., KODAMA, H., PAN, J., SANO, M., TAKAHASHI, T., HORI, S., OGAWA, S. et al. (1999). Cardiomyocytes can be generated from marrow stromal cells in vitro. J Clin Invest. 103: 697-705.

MARTIN, G. R. (1981). Isolation of a pluripotent cell line from early mouse embryos cultured in medium conditioned by teratocarcinoma stem cells. Proc. Natl Acad. Sci. USA 78 : 7634-7638.

MATSUDA, T., NAKAMURA, T., NAKAO, K., ARAI, T., KATSUKI, M., HEIKE, T. and YKOTA, T. (1999). STAT3 activation is sufficient to maintain an undifferentiated state of mouse embryonic stem cells. EMBO J 18:4261-4269.

McKay, R. (1997). Stem cells in the central nervous system. Science 276: 66-71.

NIWA, H., BURDON, T. and SMITH, A. (1998). Self-renewal of pluripotent embryonic stem cells is mediated via activation of STAT3. Genes Dev.12: 2048-2060.

OKITA, K., ICHISAKA, T. and YAMANAKA, S. (2007). Generation of germline-competent induced pluripotent stem cells. Nature $448: 313-317$.

OLSON, E. N. and SCHNEIDER, M. D. (2003). Sizing up the heart: development redux in disease. Genes Dev 17: 1937-1956.

PANDUR, P., Läsche, M., EISENBERG, L. M. and Kühl, M. (2002). Wnt-11 activation of a non-canonical Wnt signalling pathway is required for cardiogenesis. Nature 418: 636-641.

PEASE, S., BRAGHETTA, P., GEARING, D., GRAIL, D. and WILLIAMS, R. L. (1990). Isolation of embryonic stem (ES) cells in media supplemented with recombinant leukemia inhibitory factor (LIF). Dev Biol. 141: 344-352.

SASAKI, E., SUEMIZU, H., SHIMADA, A., HANAZAWA, K., OIWA, R., KAMIOKA, M., TOMIOKA, I., SOTOMARU, Y., HIRAKAWA, R., Nomura, T. et al. (2009). Generation of transgenic non-human primates with germline transmission. Nature 459: 523-527.

SATO, G. H., SATO, J. D., OKAMOTO, T., McKeehan, W. L. and BARNES, D. W. (2010) Tissue culture: the unlimited potential. In Vitro Cell Dev Biol Anim. 46: 590-594.

SATO, J. D., KAWAMOTO, T. and OKAMOTO, T. (1987). Cholesterol requirement of P3-X63-Ag8 and X63-Ag8.653 mouse myeloma cells for growth in vitro. J Exp Med, 165: 1761-1766

SHIMOJI, K., YUASA, S., ONIZUKA, T., HATTORI, F., TANAKA, T., HARA, M., OHNO, Y., CHEN, H., EGASGIRA, T., FUKUDA, K. et al. (2010). G-CSF Promotes the Proliferation of Developing Cardiomyocytes In Vivo and in Derivation from ESCs and iPSCs. Cell Stem Cell 6: 227-237.

SILVA, J., BARRANDON, O., NICHOLS, J., KAWAGUCHI, J., THEUNISSEN, T. W. and SMITH, A. (2008). Promotion of Reprogramming to Ground State Pluripotency by Signal Inhibition. PLoS Biol 6: e253.

SMITH, A. G., HEATH, J. K., DONALDSON, D. D., WONG, G. G., MOREAU, J., STAHL, M. and ROGERS, D. (1988). Inhibition of pluripotential embryonic stem cell differentiation by purified polypeptides. Nature 336: 688-690.

TAKAHASHI, K. and YAMANAKA, S. (2006). Induction of pluripotent stem cells from mouse embryonic and adult fibroblast cultures by defined factors. Cell126:663-676.

TAKAHASHI, K. OKITA, K., NAKAGAWA, M. and YAMANAKA, S. (2007). Induction of pluripotent stem cells from fibroblast cultures. Nat Protoc 2: 3081-3089.

TODARO, G. J. and GREEN, H. (1963). Quantitative studies of the growth of mouse embryo cells in culture and their development into established lines. $J$ Cell Biol. 17: 299-313.

TOUMADJE, A., KUSUMOTO, K., PARTON, A., MERICKO, P., DOWELL, L., MA, G., CHEN, L., BARNES, D. W. and SATO, J. D. (2003). Pluripotent differentiation in vitro of murine ES-D3 embryonic stem cells. In Vitro Cell Dev BiolAnim 39:449-453.

WILLIAMS, R. L., HILTON, D. J., PEASE, S., WILLSON, T. A., STEWART, C. L., GEARING, D. P., WAGNER, E. F., METCALF, D., NICOLA, N. A. and GOUGH, N. M. (1988). Myeloid leukaemia inhibitory factor maintains the developmental potential of embryonic stem cells. Nature 336: 684-687.

YANG, J. van OOSTEN, A. L., THEUNISSEN, T. W., GUO, G., SILVA, J. C. and SMITH, A. (2010). Stat3 activation is limiting for reprogramming to ground state pluripotency. Cell Stem Cell 7: 319-328.

YING, Q. L., NICHOLS, J., CHAMBERS, I. and SMITH, A. (2003). BMP induction of Id proteins suppresses differentiation and sustains embryonic stem cell self-renewal 
in collaboration with STAT3. Cell 115: 281-292.

YING, Q. L., WRAY, J., NICHOLS, J., BATLLE-MORERA, L., DOBLE, B., WOODGETT, J., COHEN, P. and SMITH A. (2008). The ground state of embryonic stem cell self-renewal. Nature 453: 519-523.
YUASA, S., ITABASHI, Y., KOSHIMIZU, U., TANAKA, T., SUGIMURA, K., KINOSHITA, M., HATTORI, F., FUKAMI, S., SHIMAZAKI, T., FUKUDA, K. et al. (2005). Transient inhibition of BMP signaling by Noggin induces cardiomyocyte differentiation of mouse embryonic stem cells. Nat Biotechnol. 23: 607-611.

\section{Further Related Reading, published previously in the Int. J. Dev. Biol.}

Induction of differentiation of undifferentiated cells into pancreatic beta cells in vertebrates Masaki Hosoya, Yuya Kunisada, Akira Kurisaki and Makoto Asashima

Int. J. Dev. Biol. (2012) 56: 313-323

Growth factor-defined culture medium for human mesenchymal stem cells

Sumiyo Mimura, Naohiro Kimura, Mitsuhi Hirata, Daiki Tateyama, Midori Hayashida, Akihiro Umezawa, Arihiro Kohara, Hiroki Nikawa, Tetsuji Okamoto and Miho K. Furue

Int. J. Dev. Biol. (2011) 55: 181-187

Enhancing somatic nuclear reprogramming by Oct4 gain-of-function in cloned mouse embryos

Martin J. Pfeiffer, Sebastian T. Balbach, Telma C. Esteves, Nicola Crosetto and Michele Boiani Int. J. Dev. Biol. (2010) 54: 1649-1657

Induction of neural crest cells from mouse embryonic stem cells in a serum-free monolayer culture

Yuko Aihara, Yohei Hayashi, Mitsuhi Hirata, Nobutaka Ariki, Shinsuke Shibata, Narihito Nagoshi, Mio Nakanishi, Kiyoshi Ohnuma, Masaki Warashina, Tatsuo Michiue, Hideho Uchiyama, Hideyuki Okano, Makoto Asashima and Miho Kusuda Furue

Int. J. Dev. Biol. (2010) 54: 1287-1294

Feeder- and serum-free establishment and expansion of human induced pluripotent stem cells

Mehdi Totonchi, Adeleh Taei, Ali Seifinejad, Mohammadsharif Tabebordbar, Hassan Rassouli, Ali Farrokhi, Hamid Gourabi, Nasser Aghdami, Ghasem Hosseini-Salekdeh and Hossein Baharvand

Int. J. Dev. Biol. (2010) 54: 877-886

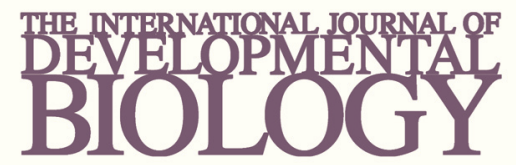

Volume 54 Nos. 6/7

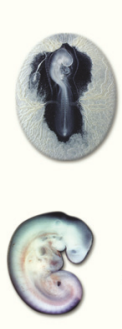

Special Issue

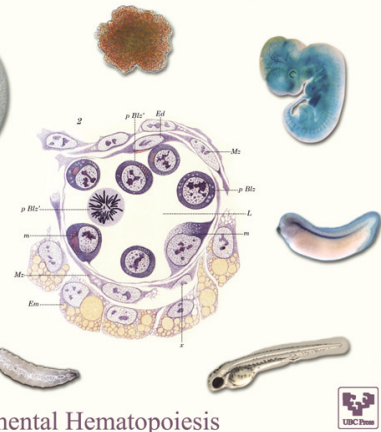

5 yr ISI Impact Factor $(2011)=2.959$

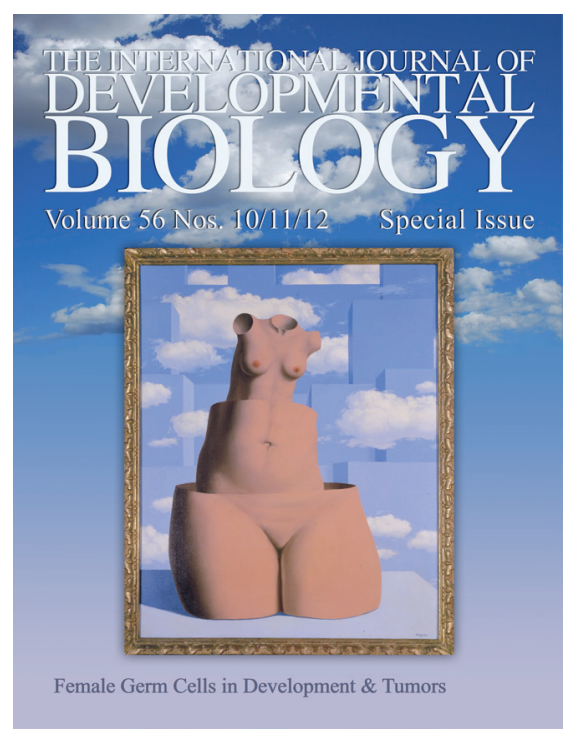

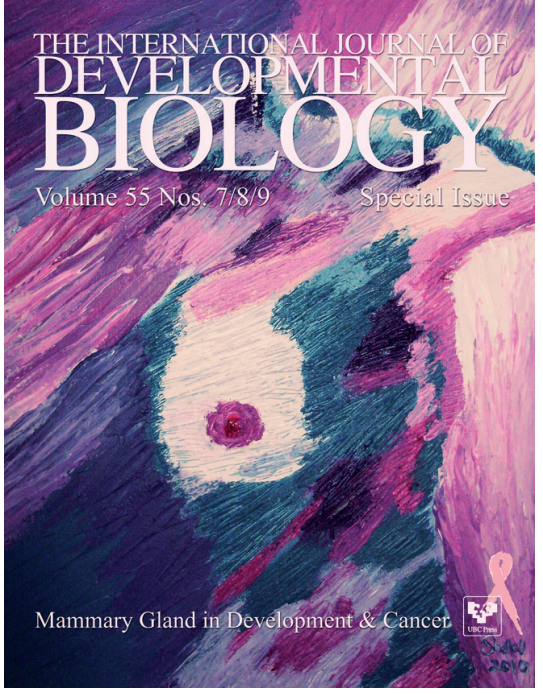

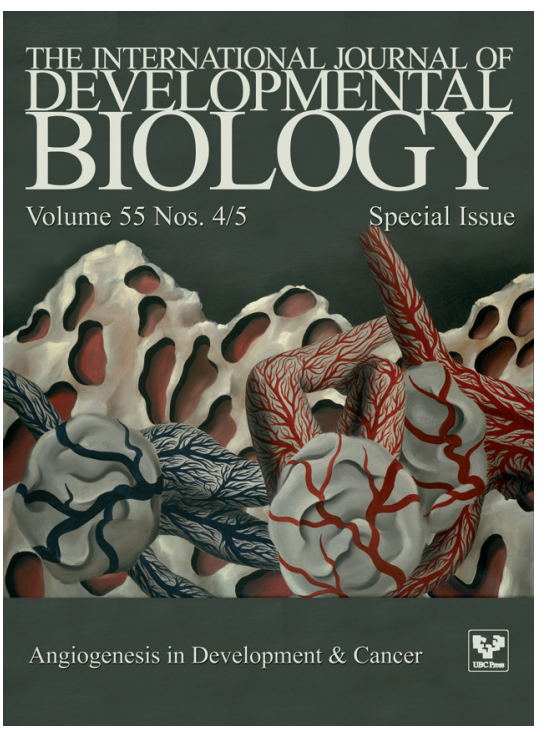

